Original Paper

\title{
Pendidikan Lingkungan Sebagai Media Pengenalan Sains dan Teknologi Bagi Siswa Menegah di Kabupaten Lombok Barat
}

\author{
Immy Suci Rohyani ${ }^{*}$, Hilman Ahyadi ${ }^{1}$ \\ ${ }^{1}$ Program Studi Biologi Fakultas MIPA Universitas Mataram, Indonesia
}

DOI: 10.29303 /jpmpi.v2i1.359

Sitasi: Rohyani, I. S., Ahyadi, H. (2019). Pendidikan Lingkungan Sebagai Media Pengenalan Sains Dan Teknologi Bagi Siswa Menegah Di kabupaten Lombok Barat. Jurnal Pengabdian Magister Pendidikan IPA (JPMPI). (2) 1. pp. $79-84$

*Corresponding Author: Immy Suci Rohyani, Program Studi Biologi Fakultas MIPA Universitas Mataram, Indonesia;

Email: immysuci@yahoo.co.id

\begin{abstract}
Perkembangnnya sains dan teknologi akhir-akhir ini menuntut perlunya inovasi dibidang pendidikan dan pengajaran sains, agar siswa termotivasi dalam mengikuti pembelajaran. Pembelajaran sains dan teknologi dengan pendekatan pendidikan lingkungan ternyata mampu meningkatkan pemahaman siswa terhadap ilmu sains. Kegiatan ini bertujuan Memperkenalkan kepada siswa menengah khususnya yang berada di Kabupaten Lombok Barat terhadap permasalahan lingkungan yang terjadi. Meningkatkan ketertarikan siswa terhadap pembelajaran sains melalui konsep pendidikan lingkungan dan meningkatkan minat siswa menengah untuk melanjutkan pendidikan ke perguruan tinggi basic sains. Manfaat dari kegiatan ini diharapkan siswa menengah khususnya yang berada di Kabupaten Lombok Barat semakin tertarik belajar sains dan teknologi melalui pendekatan pendidikan lingkungan serta menumbuhkan kesadaran siswa terhadap permasalahan lingkungan yang terjadi dan pada akhirnya semakin banyak siswa yang tertarik untuk melanjutkan keperguruan tinggi basic sains. Metode yang digunakan untuk kegiatan pendidikan lingkungan dan pembelajaran sains dan teknologi yaitu Focus Group Discuss (FGD) yang dilakuakan di lapangan. Praktik langsung pengenalan konsep pembelajaran di lapangan. Sosialisasi perguruan tinggi dilakukan melalui seminar yang menghadirkan tokoh-tokoh inspiratif dan alumni serta kunjungan langsung ke laboratorium dan fasilitas umum yang menunjang proses pembelajaran. Luaran dari kegiatan ini diharpkan dapat meningkatnya keperdulian siswa terhadap permasalahan lingkungan yang terjadi belakangan ini, meningkatnya jumlah siswa menengah yang tertarik belajar sains dan teknologi, meningkatkan jumlah siswa yang tertaik melanjutkan ke perguruan tinggi basic sains.
\end{abstract}

Kata Kunci: Pendidikan Lingkungan; Sains dan Teknologi; Siswa Menegah.

\section{Pendahuluan}

Berkembangnnya sains dan teknologi akhir-akhir ini menuntut perlunya inovasi dibidang pendidikan dan pengajaran sains. Hal ini mengingat bahwa sains dan teknologi berperan dalam meningkatkan kesejahteraan masyarakat. Inovasi yang dilakukan merupakan upaya untuk mewujudkan tantangan kebutuhan masyarakat akan pendidikan dan pengajaran sains dan teknologi yang memberikan bekal kepada anak didik, sehingga mereka kelak dapat menyesuaikan diri dalam kehidupan masyarakat yang sudah makin terikat pada kemajuan-kemajuan sains serta hasilhasilnya dibidang teknologi.

Memperkenalkan sains dan teknologi membutuhkan inovasi agar siswa termotivasi dalam mengikuti pembelajaran sains. Siswa yang mempelajari sains melalui pengalaman langsung akan lebih menghayati pelajaran sains itu sendiri. Sebagai contoh adalah pelajaran sains biologi dan kimia. Siswa diajak ke alam dan melakukan pengamatan langsung dengan melihat, mendengar dan merasakan sendiri semua fenomena yang terjadi di alam. Pengalaman ini akan membuat sisiwa menjadi senang dan meningkatkan 
pemahaman mereka mengenai sains dan teknologi yang ada. Menurut Subagyo (2006), pembelajaran sains juga dapat dikembangkan dengan memberikan serangkaian keterampilan di bidang sains kepada siswa. Keterampilan ini dapat diperoleh langsung di alam maupun di laboratorium. Keterampilan ini akan menjadi modal bagi siswa untuk memecahkan permasalahan di bidang sains dan teknologi.

Pembelajaran sains dan teknologi dengan pendekatan pendidikan lingkungan ternyata mampu meningkatkan pemahaman siswa terhadap ilmu sains. Hal ini dibuktikan oleh Subarno (2013) dimana terjadi peningkatan ketertarikan belajar siswa dari $62 \%$ menjadi $93 \%$. Hasil serupa juga diperoleh oleh Yenimar (2013) yang melihat adanya peningkatan kemampuan sains flora anak melalui pembelajaran sains berbasis alam.

Menyadari pentingnya pembelajaran sains dan teknologi berbasis pendidikan lingkungan, perlu adanya upaya untuk mensosialisasikan konsep pembelajaran tersebut kepada siswa menengah khususnya yang berada di wilayah Kabupaten Lombok Barat. Kabupaten Lombok Barat memiliki wilayah yang sangat luas dan memiliki potensi yang sangat besar untuk pengembangan sains dan teknologi maupun pariwisata karena memiliki sumberdaya alam yang sangat melimpah namun belum terjamah oleh teknologi ditambah dengan panorama alam yang sangat indah sehingga sangat menjanjikan untuk pengembangan industri maupun pariwisata yang ramah lingkungan. Kondisi tersebut tidak sebanding dengan pengembanagn sumberdaya manusianya pengelolanya.

Tingkat pendidikan dan pemahaman masyarakat yang masih rendah, sehingga masih sedikit masyarakat yang tertarik melanjutkan keperguruan tinggi, akses informasi yang kurang, sehingga pemahaman terhadap perkemabangan sains dan teknologi juga rendah. Kondisi tersebut menyebabkan masyarakat kurang perduli terhadap permasalah lingkungan sehingga cenderung untuk melakukan eksploitasi terhadap sumberdaya alam. Pendidikan lingkungan yang menjadi dasar dalam pengenalan sains dan teknologi akan membuat sisiwa lebih dekat dan perduli dengan lingkungannya serta lebih peka terhadap fenomena yang terjadi. Konsep pendidikan lingkungan ini akan mengajak siswa secara langsung terjun ke alam dan menjadikan alam sebagai lingkungan belajar, laboratorium, tempat siswa berdiskusi, dan memahami teori-teori sains sehingga nantinya mereka diharapkan dapat memecahkan berbagai permasalahan sains dan teknologi di masyarakat.

Penelitian ini bertujuan untuk Memperkenalkan kepada siswa menengah khususnya yang berada di Kabupaten Lombok Barat terhadap permasalahan lingkungan yang terjadi, Meningkatkan ketertarikan siswa terhadap pembelajaran sains melalui konsep pendidikan lingkungan, Meningkatkan minat siswa menengah untuk melanjutkan pendidikan ke perguruan tinggi basic sains. Penelitian ini diharapkan dapat memberi manfaat bagi siswa menengah khususnya yang berada di Kabupaten Lombok Barat semakin tertarik belajar sains dan teknologi melalui pendekatan pendidikan lingkungan serta menumbuhkan kesadaran siswa terhadap permasalahan lingkungan yang terjadi dan pada akhirnya semakin banyak siswa yang tertarik untuk melanjutkan keperguruan tinggi basic sains.

\section{Metode Pelaksanaan}

Metode yang digunakan untuk kegiatan pendidikan lingkungan dan pembelajaran sains dan teknologi yaitu Focus Group Discuss (FGD) yang dilakuakan di lapangan. Sebelum kegiatan FGD dilakukan siswa diperkenalkan konsep pembelajaran di lapangan seperti pengenalan flora dan fauna serta interaksinya dengan lingkungan, kegiatan ini dilakukan melalui serangkaian gamegame edukasi yang menyenagkan yang akan meningkatakan pemahaman dan keperdulian siswa terhadap lingkungan sekitar. Sosialisasi perguruan tinggi dilakukan melalui seminar yang menghadirkan tokoh-tokoh inspiratif dan alumni serta kunjungan langsung ke laboratorium dan fasilitas umum yang menunjang proses pembelajaran.

\section{Hasil dan Pembahasan}

Model pembelajaran sains dan teknologi merupakan model pembelajaran yang bertujuan menyajikan konteks dunia nyata dalam pendidikan dan pendalaman sains (Hendri, 2008). Menurut Galib dalam Jannah (2007) bahwa program pembelajaran sains dan teknologi adalah belajarmengajar sains dan teknologi dalam konteks pengalaman dalam kehidupan manusia sehari-hari, dengan fokus isu-isu atau masalah-masalah yang 
sedang dihadapi masyarakat, baik bersifat lokal, regional, nasional, maupun global yang memiliki komponen sains dan teknologi. Pendapat ini sejalan dengan NSTA (National Science Teachers Association) di Amerika (1990) yang memandang sains dan teknologi sebagai pengajaran dan pembelajaran sains dalam konteks pengalaman manusia.

Kegiatan pengabdian ini menunjukan hasil yang sangat positif, hal ini dapat terlihat dari adanya respon dan apresiasi yang sangat positif dari peserta untuk mengikuti kegiatan ini dari awal hingga akhir acara. Respon positif ini juga terlihat dari jumlah peserta dan respon sekolah yang mengirim utusannya untuk menghadiri kegiatan pengabdian ini. Selama kegiatan berlangsung peserta sangat antusias mengikuti kegiatan ini. Anstusiasme mereka nampak dari semangat mereka untuk bertanya dan berdiskusi dengan Tim Pengabdian selama penyampaian materi ceramah maupun selama kegiatan praktik lapangan berlangsung.

Menurut Galib (2002), bahwa pendekatan sains teknologi adalah belajar dan mengajarkan sains dan teknologi dalam konteks pengalaman manusia. Pendekatan sains teknologi masyarakat cocok untuk mengintegrasikan domain konsep, keterampilan proses, kreativitas, sikap, nilai-nilai, penerapan dan keterkaitan antar bidang studi (kurikulum) dalam pembelajaran dan penilaian pendidikan sains. Pendekatan sains teknologi menekankan pada konteks pembelajaran dan beraneka ragam hasil belajar. Salah satu ciri utama pendekatan Sains Teknologi adalah mempelajari isi kurikulum dengan bertitik tolak dari masalahmasalah yang dihadapi siswa dalam kehidupan sehari-hari yang mengandung komponen sains dan teknologi. Dalam pembelajaran Sains dan teknologi siswa berpartisipasi langsung dan pro-aktif dalam upaya pemecahan masalah-masalah yang sedang dihadapi dalam kehidupan sehari-hari (Galib, 2002).

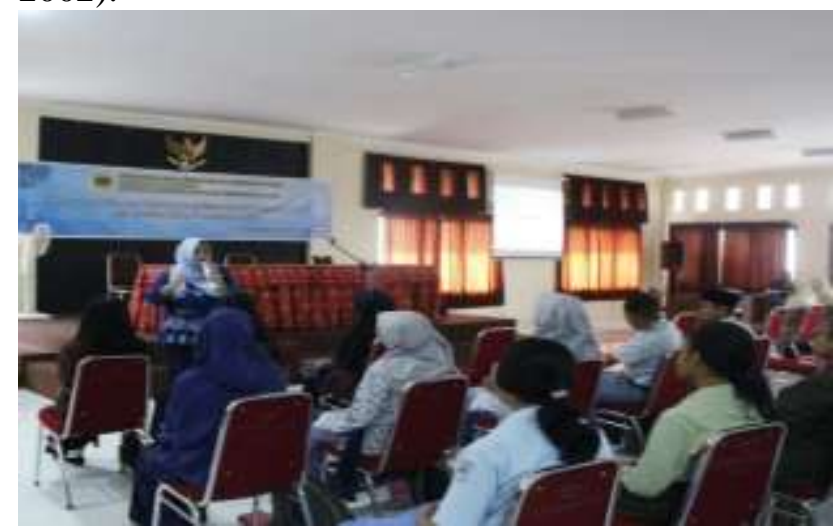

Gambar 1. Diskusi umum tema sains dan teknologi yang diikuti peserta dengan antusias

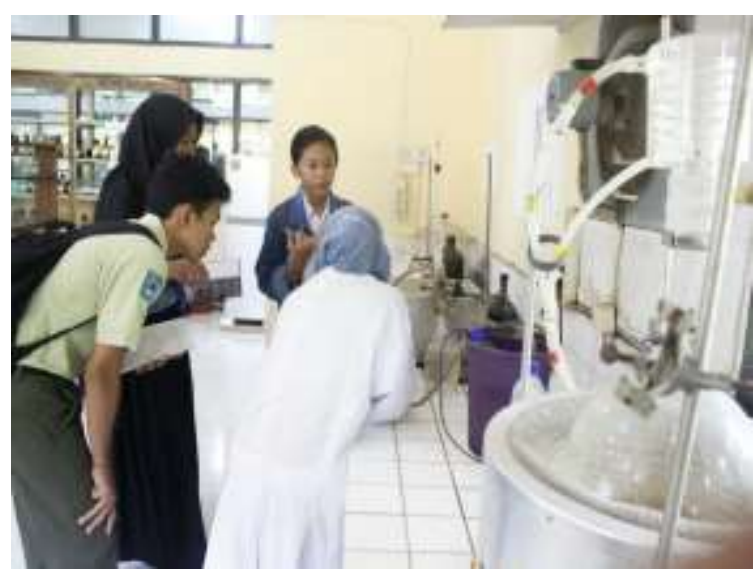

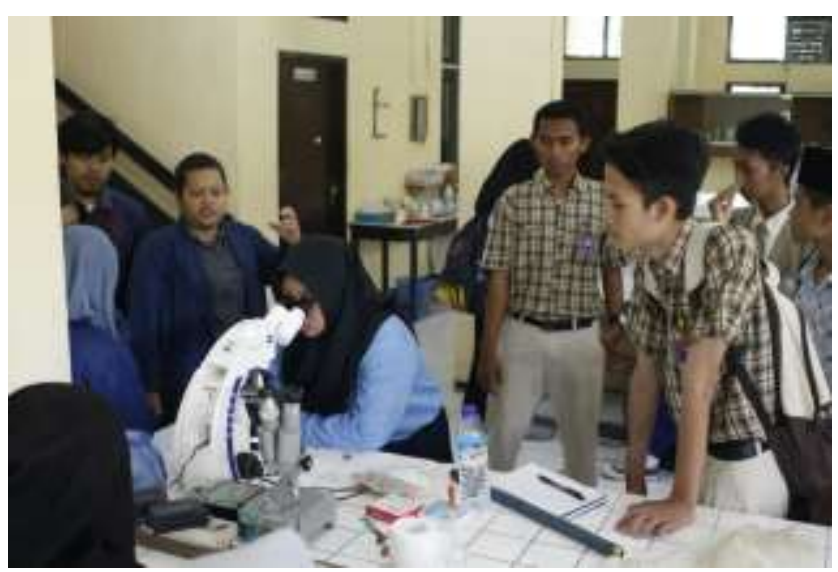

Gambar 2. Belajar dan Mengamati obyek secara langsung di laboratorium

Umumnya peserta sangat antusias karena selama ini belum memahami lebih dalam tentang sains dan teknologi serta manfaatnya. Bagi mereka pengenalan sains dan teknologi sangat menyenagkan jika dilakukan dengan pendekatan pendidikan lingkungan. Kegiatan eksplorasi lingkungan membuat mereka lebih dalam mengenal keragaman jenis tumbuhan dan manfaatnya serta mencoba membuat herbarium sederhana. Peserta juga melakukan identifikasi serangga dan membuat awetan basah dan kering serta melakukan pengamatan dan pengenalan beragam jenis burung yang mereka temukan. Kegiatan pembelajaran tidak hanya berlangsung diluar rungan tetapi juga 
kegiatan didalam runagn tidak kalah seru dan menariknya karena peserta diajak mengamati bagaimana reaksi asam basa yang sering kali mereka temukan dalam kehidupan sehari-hari, melakukan titrasi dan pencampuran bahan dan melihat reaksi-reaksi kimia yang terjadi memberi daya tarik tersendiri dan memberi pengalaman mendalam bagi peserta. Para peserta pelatihan pada umumnya sangat tertarik untuk melajutkan pendidikan mereka pada perguruan tinggi basic sains setelah mereka mengetahui peluang kerja kedepannya yang cukup menjanjikan dan konsep pembelajaran sehingga dapat menghasilkan pengetahuan yang menyeluruh yang dapat mereka aplikasikan dalam kehidupan mereka nantinya.

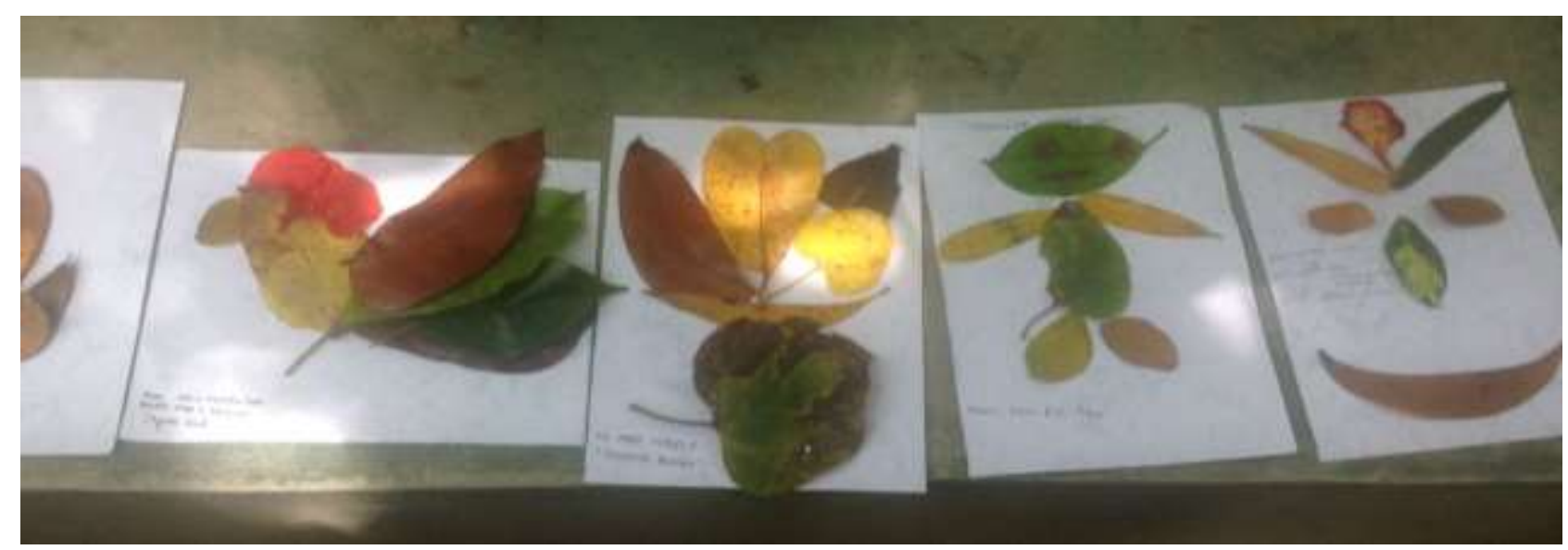

Gambar 3. Identifikasi tumbuhan dengan cara mengumpulkan daun dan membuat karya sederhana
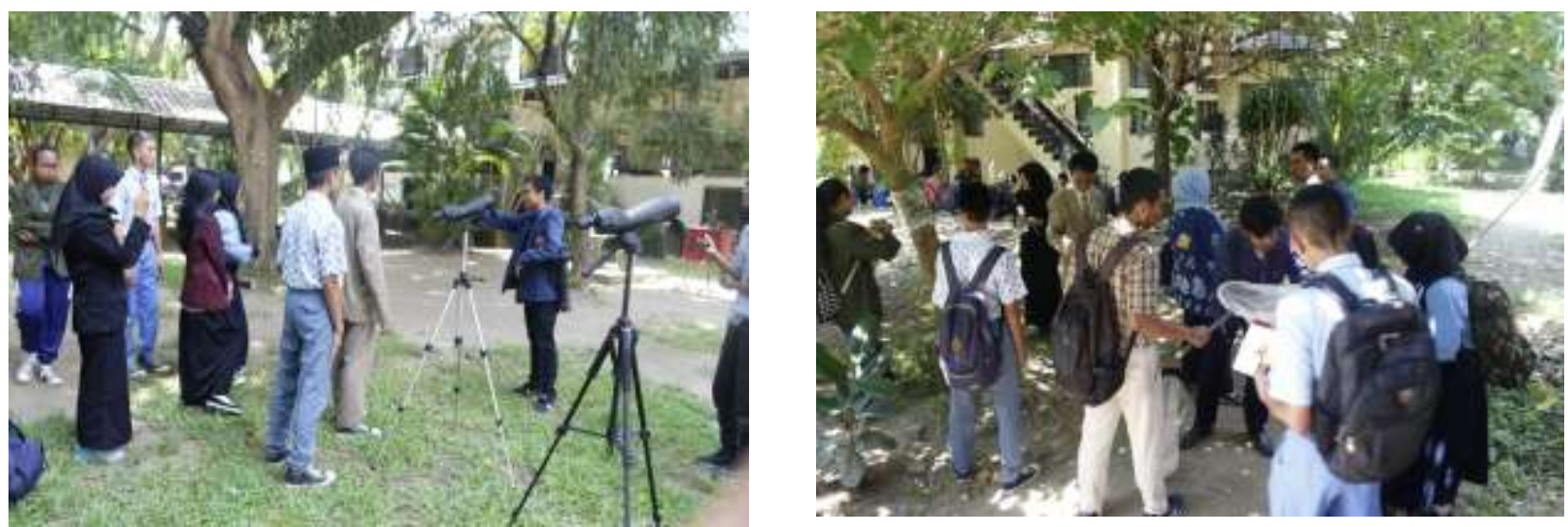

Gambar 4. Identifikasi burung dan serangga di lingkungan sekitar

Pendidikan sains memiliki peran yang penting dalam menyiapkan siswa memasuki dunia kehidupannya dimana sains melandasi perkembangan teknologi, sedangkan teknologi menunjang perkembangan sains. Sains digunakan untuk aktivitas penemuan dalam upaya memperoleh penjelasan tentang objek dan fenomena alam serta untuk aktivitas penemuan berupa rumus-rumus. Teknologi merupakan aplikasi sains yang digunakan untuk memenuhi kebutuhan masyarakat, sehingga pengembangan teknologi selalu dikaitkan dengan kebutuhan masyarakat termasuk ilmu-ilmu biologi yang merupakan bagian dari sains.
Pengajaran sains pada pendidikan dasar dan menengah pada umumnya terbagi dalam dua bagian besar yaitu sains sebagai produk dan sains sebagai proses (Sumintono, 2007). Konteks sains sebagai produk adalah pada pengajaran tentang fakta, teori, prinsip dan hukum alam; sedangkan sains sebagai proses adalah pengembangan kemampuan siswa dalam metoda ilmiah dan pemecahan masalah sains. Terdapat berbagai tantangan dalam pengajaran sains di sekolah. Bybee dan Fuchs (2006) misalnya mengemukakan perlunya reformasi pengajaran sains supaya lebih relevan dengan tantangan abad baru. Hal mendasar yang perlu diperbaiki isunya masih sama yaitu: guru 
yang berkualitas, isi kurikulum yang tepat dan berkesinambungan, tes belajar yang sesuai dan sistem penilaian yang terkait dengan tujuan pembelajaran.

Adapun faktor lain yang menyebabkan kurang menariknya pelajaran sains disekolah disebabkan karena keterbatasan sarana prasarana seperti laboratorium untuk pelaksanaan praktikum di beberapa sekolah. Menurut Sukarso (2005) laboratorium ialah suatu tempat dimana dilakukan kegiatan kerja untuk menghasilakan sesuatu. Tempat ini dapat merupakan suatu ruangan tertutup, kamar, atau ruangan terbuka, kebun botani dan lain-lain. Pengelola sekolah dan guru sering kali beranggapan bahwa pengamatan/observasi, percobaan, dan pekerjaan laboratorium seringkali dikaitkan dengan peralatan yang banyak dan mahal, ruangan yang luas dan lain-lain.

Menghadapi persoalan tersebut solusi yang dapat dilakukan yaitu dengan memanfaatkan alam sekitar sebagai laboratorium terbuka yang dapat dimanfaatkan untuk berbagai pengamatan percobaan dan praktikum. Laboratorium alam, yaitu seisi alam yang ada di sekitar kita baik yang asli maupun buatan manusia sering terabaikan untuk kegiatan praktikum. Selain itu, siswa akan sangat tertarik jika observasi pembelajaran sains dan teknologi memanfaatkan wahana alam sekitar. Observasi yang demikian akan dapat meningkatkan minat belajar siswa terhadap pembelajaran sains dan teknologi. Ketertarikan siswa pada pembelajaran sains dan teknologi, harus dilakukan secara bertahap dan akrab dengan lingkungan sekitar sehingga pemanfaatan laboratorium alam sebagai sarana untuk meningkatkan kompetensi guru pada pembelajaran sains dan teknologi dan meningkatkan minat belajar siswa perlu dilakukan.

Keberadaan praktikum menyebabkan pembelajaran sains dan teknologi menjadi lebih jelas. Ruang laboratorium tidak banyak ditemui bahkan hampir tidak disediakan di setiap Sekolah. Oleh karena itu dengan adanya laboratorium alam, guru dapat memanfaatkan alam sekitar dalam menjelaskan fenomena fisika dengan lebih mudah. Dengan adanya laboratorium alam ini pembelajaran sains dan teknologi menjadi menyenangkan karena diberikan contoh seperti dalam kehidupan seharihari dan menghindari banyak hapalan. Keberadaan praktikum yang menggunakan laboratorium alam ternyata mampu meningkatkan minat belajar sains dan teknologi. Dengan menggunakan laboratorium alam maka siswa akan dengan mudah untuk memahami materi karena kegiatan praktikum ini menggunakan bahan dan alat yang sering dijumpai dalam kehidupan sehari-hari siswa. Dengan adanya kegiatan ini, diharapkan para guru dapat melakukan kegiatan percobaan praktikum sebagai sarana mengajar sains dan teknologi. Hasil dari pembuatan perangkat percobaan dengan memanfaatkan laboratorium alam selanjutnya dapat dijadikan pilot project agar para siswa senang dalam melakukan praktikum. Selanjutnya guru dapat mengembangkan praktikum sains dan teknologi sesuai dengan kondisi alam sekitar.

Berdasarkan hasil analisis yang dilakukan tim pengabdian masyarakat terdapat Beberapa faktor penghambat yang ditemukan pada kegiatan pengabdian ini adalah: 1) Adanya persepsi awal peserta bahwa basic sains sebagai pembelajaran yang sulit bahkan menakutkan serta membosankan dan tidak memiliki prospek pengembangan ke depan atau akan kesulitan dalam mencari pekerjaan. 2) Peserta masih belum dapat menentukan apa yang menjadi cita-cita atau kesukaan mereka atau belum dapat menyusun rencana pembelajaran mereka kedepan.

Terdapat beberapa Faktor Pendorong sehingga kegiatan ini sukses dan mendapat respon positif dari peserta adalah: 1) Adanya keberpihakan dari pihak sekolah untuk medukung siswanya melajutkan pendidikan kejejang yang lebih tingi. 2) Respon dan apresiasi yang tinggi dari peserta kegiatan pengabdian yang berasal dari siswa menengah yang ada di Kabupaten Lombok Barat. 3) Penyajian materi yang dikemas dengan cara menyenagkan, dengan game dan aplikasi sederhana yang dapat diterapkan dan sesuai dengan kehidupan peserta sehari-hari. 4) Mentor atau tim pengabdian sangat apik dalam menyajikan materi membuat suasan selalu hidup dan selalu dapat membangitkan semangat peserta untuk terlibat.

Upaya pencapaian pembelajaran sains dan teknologi untuk hasil yang optimal perlu diperhatikan beberapa prinsip pembelajaran. prinsip pembelajaran dibangun atas dasar prinsisp-prinsip yang ditarik dari teori psikologi terutama teori belajar dan hasil-hasil penelitian dalam kegiatan pembelajaran dan pelasanakan pembelajaran. Selain itu dengan cara memberikan dasar-dasar teori untuk membangun sistem intruksional yang berkualitas tinggi. Pada dasarnya pembelajaran sains dan teknologi berupaya untuk membekali siswa dengan berbagai kemampuan tentang cara mengetahui dan memahami konsep ataupun fakta secara mendalam. 
Pembelajaran sains dan teknologi seharusnya efektif dapat menampung kesenangan dan kepuasan intelektual siswa dalam usahanya untuk mengali berbagai konsep. Pada akhirnya diharapkan dapat tercapai pembelajaran sains dan teknologi yang memuaskan dan efetif.

\section{Kesimpulan}

Kesimpulan yang dapat diambil dari kegiatan pengabdian masyarakat adalah bahwa sosialisasi dan pelatihan ini telah berhasil menstimulasi peserta serta memberikan gambaran secara nyata tentang konsep dan prospek pembelajaran sains dan teknologi dimasa yang akan datang. Kegiatan ini juga berhasil menumbuhkan minat siswa untuk melajutkan pendidikan kejenjang yang lebih tinggi terutaa pendidiakn yang berdasarkan sains dan teknologipeserta pelatihan dalam praktikum dan penelitian.

\section{Saran}

Kegiatan semacam ini sangat baik untuk dilakukan secara berkelanjutan sehingga lebih banyak sekolah-sekolah menengah yang merasakan manfaatnya. Lebih dari itu pelatihan yang menyangkut transfer pengetahuan butuh tidak lanjut dengan terus melakuakan pembinaan dan pendekatan baik secara formal maupun nonformal dengan mengoptimalkan peranan osis yang ada disekolah masing-masing sehingga manfaatnya dapat dirasakan oleh seluruh siswa menegah.

\section{Daftar Pustaka}

Bybee, R.W. \& Fuchs, B. (2006). Preparing the $21^{\text {st }}$ Century Workforce: A New Reform in Science and Technology Education. Journal of Research in Science Teaching. 43 (4): 349-352.

Galib, L. M. (2002). Pendekatan Sains-TeknologiMasyarakat dalam Pembelajaran Sains di Sekolah. Jurnal pendidikan dan kebudayaan, 34 (1), hlm. 1-31). Tersedia pada http://www.depdiknas.go.id. Diunduh tanggal 25 juni 2016

Hendri E. (2008). Model Pembelajaran Alternatif
Untuk Pendidikan Sains $V$, (online), www.docstoc.com/docs.../Metodolog-IPASD_5, diunduh 6 Agustus 2009.

NSTA. (1990). Science/Technology/Society: A New Effort for Providing Appropriate Science for All, (online), http://www.nsta.org/about/position/sts.aspx, diunduh 13 April 2009.

Sagala, S. (2003). Konsep dan Makna Pembelajaran. Bandung: CV Alfabeta

Subagyo, Y. (2006). Pembelajaran Sains Dengan Pendekatan Keterampilan Proses Untuk Meningkatkan Hasil Belajar Siswa Sekolah Menengah Pertama Dalam Pokok Bahasan Suhu dan Pemuaian, Skripsi : Jurusan Fisika, Fakultas Matematika dan Ilmu Pengetahuan Alam, Universitas Semarang.

Subarno, (2013. Penggunaan Direct Instruction Berbasis Lingkungan Untuk Peningkatan Domain Afektif IPA Fisika Pada Siswa Kelas VIIB SMP Negeri 28 Purworejo Tahun Pelajaran 2012/2013, Radiasi, 2 (1), hal : $24-26$.

Sukarso. (2005). Pengertian dan Fungsi Laboratorium. Online http://wanmustafa.wordpress.com/2011/06/1 2/pengertian-dan-fungsi-laboratorium/ diakses pada tanggal 03 Maret 2015 pukul 14.24

Sumintono, B. (2007). Apakah Sains itu? Available at: http://deceng.wordpress.com/2007/11/07/apa kah-sains-itu/

Taufik, M., N.S. Sukmadinata, I. Abdullah, dan B.Y. Tumbelaka, (2010). Desain Model Pembelajaran Untuk Meningkatkan Kemampuan Pemecahan Masalah Dalam Pembelajaran IPA (Fisika) Sekolah Menengah Pertama di Kota Bandung, Berkala Fisika, 13(2), hal : $31-44$.

Jannah, U. N. F. 2007. Dari Jurnal Pendidikan, (online), http://omifatiha.blogspot.com/2007/09/darijurnal-pendidikan.html, diunduh 28 Agustus 2009

Yenimar. (2013). Peningkatan Kemampuan Sains Flora Anak Dengan Pembelajaran Berbasis Alam di PAUD. Spektrum PLS, 1 (1), hal : $218-234$. 